\title{
Rainwater Harvesting-Based Marginal Land Irrigation Technology: A Case Study in Ngawen Sub-district of Gunungkidul Regency, Indonesia
}

\section{Widodo Brontowiyono ${ }^{\mathrm{a}^{*}}$, Ribut Lupiyanto ${ }^{\mathrm{b}}$, Eko Yuwono ${ }^{\mathrm{b}}$, Bambang Sulistiono ${ }^{\mathrm{c}}$, Suci Handayani $^{\mathrm{d}}$, Dwipraptono Agus Harjito ${ }^{\mathrm{e}}$}

\author{
${ }^{a}$ Department of Environmental Engineering of Universitas Islam \\ Indonesia (UII), Yogyakarta, Indonesia \\ ${ }^{b}$ Center for Climate Change, Disaster, and Environmental Study \\ (PuSPIK) of UII, Yogyakarta, Indonesia \\ 'Department of Civil Engineering of UII, Yogyakarta, Indonesia \\ ${ }^{d}$ Department of Soil, Faculty of Agriculture, Gadjah Mada University, \\ Yogyakarta, Indonesia \\ ${ }^{e}$ Department of Management, Faculty of Economy of UII, Yogyakarta, \\ Indonesia
}

Received: March 7, 2013/ Accepted: September 25, 2013

\begin{abstract}
Gunungkidul Regency is an area that has both potential and problems in achieving food stability. Though agriculture in this region makes the highest contribution to Gross Regional Domestic Product, the productivity of this sector is still low. Drought is a classic problem and represents the largest barrier in agricultural development, despite high precipitation. This paper describes the design of an efficient irrigation technology to increase agricultural productivity. Specifically, this research aims to determine marginal-land suitability, analyze and design a suitable model of rainwater-harvesting-based irrigation technology. Using the method of combining field study and desktop analysis, the results indicate that the land in the research site is considered suitable given the conditions of a particular treatment for the commodities of upland rice, soybean, corn, green beans, peanuts and cassava. The model rainwater irrigation reservoir is built by considering the drainage flow and the contour of the rainwater catchment area. The feasible irrigation distribution models are the pitcher irrigation system and perforated pipe irrigation system. The pitcher system from the existing reservoir can support a maximum of $24.75 \mathrm{~m}^{2}$ of land, 120 plants and at least 66 service days. The optimum range of pitcher water is around $25 \mathrm{~cm}$ with a $50-\mathrm{cm}$ space between plants and one pitcher serving 4 plants. Meanwhile, the perforated pipe is mounted near the root zone $(10-25 \mathrm{~cm})$ at the depth of $17.5 \mathrm{~cm}$, with $25 \mathrm{~cm}$ left-right spacing between plants. An L-shaped pipe can serve 10 plants; one side is mounted underground while the other side is above the land surface for water intake. The pipe system from a reservoir can serve a maximum of $129.5 \mathrm{~m}^{2}$ land. The study results lead to the conclusion that the most suitable irrigation model in the study area is the perforated pipe system.
\end{abstract}

Keywords: irrigation, rainwater harvesting, drought, Gunungkidul.

\begin{abstract}
Corresponding Author
Tel.: +6281804213321; E-mail: widodo.bronto@uii.ac.id
\end{abstract}

\section{Introduction}

Some of the major problems faced by many regions globally in relation to sustainable agriculture are severe seasonal droughts and water shortages, low agricultural productivity, soil erosion, and fragile environments. Rainwater harvesting is often the only sustainable method available since surface and ground water are limited and reticulated water systems are not feasible because of the terrain and other factors.

As one of the regencies in the Special Province of Yogyakarta, Gunungkidul has potential to achieve food stability. However, though agriculture in this region makes the highest contribution to the Gross Regional Domestic Product, i.e. 35.4\% [1], the productivity of this sector is low. It is reported that drought or water availability has become the key hindering factor for agricultural development [2]. Very-deep groundwater aquifers or even the absence of aquifers dominate the physical characteristics of the regional environment. These characteristics also correspond to the low capacity of the land to absorb and preserve water. As a result, many marginal lands have become unproductive and tend to revert to natural vegetation. As reported by the Settlement and Regional Infrastructure Agency of DIY Province (2006), the precipitation in Gunungkidul Regency is higher than the water demand [3]. Hence, a study was deemed necessary to observe how this potential could be harnessed optimally in order to revitalize marginal lands to increase agricultural productivity.

In 2009-2010, research was conducted in Gunungkidul Regency which resulted in the recommendation of a main strategy to strengthen the environmental carrying capacity for the development of agricultural productivity in marginal lands by optimizing the use of rainwater for irrigation. This result is in line with the national strategies concerning food stability and safety. Two key issues are the actual productivity of the land and the importance of marginal land optimization for sustainable agriculture. Based on the recommendations from previous research, the current study was undertaken. The research site for this case study was a demonstration plot in Tancep Village of Ngawen District that was chosen due to its categorization as prioritized critical land, sufficient for water carrying capacity, and having suitable physical characteristics for agriculture.

The specific objectives of this research are: 1) to analyze and design irrigation models using rainwater harvesting; and 2) to analyze the feasibility of implementation of each irrigation model.

\section{Research Method}

The research method is a combination of surveys, field experiments, laboratory analysis, and desktop analysis.

\subsection{Data Collection}

Data collected in this research was data on the physical environment and socio-economic status of the population. The physical environment data consists of secondary and primary data. The collected secondary data includes:

1. Topographical Map of Indonesia for Gunungkidul Sheet at a Scale $1: \mathbf{2 5 . 0 0 0}$

2. Thematic Map: Land and Geology 
Subsequently, the purpose of the primary data was to supplement, check and complete the secondary data using field survey methods.

The socioeconomic status and population data also consisted of secondary data and primary data. Here, the secondary data was mostly collected from the statistical data issued by BPS (Indonesian Agency for

Statistics) both at the sub-district level and the regional level using time series.

\subsection{Data Analysis}

\subsubsection{Design of Rainwater Harvesting-based Irrigation Technology Model}

In order to develop the model for the rainwater harvesting irrigation, the design was based on the literature and includes topography, land use, and other physical characteristics, as per existing models. In this design, the principles of planning for safe water systems (a controlled model) was used. The model consists of the rainwater reservoir and irrigation system. Subsequently, two designed models are analyzed for their physical and economical feasibility in order to determine which model is more feasible.

\subsubsection{Analysis of Technical Feasibility}

Principally, the technical feasibility analysis refers to a hydrological analysis, measuring the optimality of a model in its function to preserve rainwater and to drain the water based on the needs of plants. This analysis is conducted with the model of the rainwater reservoir and irrigation system. The feasibility analysis of the rainwater reservoir includes catchment analysis from the catchment area and water loss analysis.

Estimates of the peak flow of a catchment area of less than 300 ha are calculated via the mathematic equation as follows [4]:

$$
\mathrm{Q}=0,002778 \text {. C.I.A }
$$

where $Q$ represents the peak discharge at $\mathrm{m}^{3} /$ second, $C$ represents the coefficient of surface flow (o $\leq \mathrm{C} \leq 1$ ), I represents the rain intensity at $\mathrm{mm} /$ hour and $A$ represents the width of catchment area in hectares. The feasibility of tanks is reflected in a condition where the existing peak discharge is able to contribute the maximum rainwater to the tanks.

Furthermore, hydrological analysis on irrigation systems was conducted to observe the optimum water level. The condition of water level hindering the growth of plants is commonly known as the initial wilting point, a minimum standard of water level needed by plants. The power of soil suction $(\mathrm{pF})$ of the water level in the initial wilting condition ranges from 3.0 to 3.6. When the water in the soil is reduced below the initial wilting point, the plant will die due to inability to absorb water. This condition was called permanent wilting point, which is fixed, not relying on the types of plant and based on the ability of the soil to hold water from $\mathrm{pF}=4.0$ to 4.30 . The interval of water level within which it is possible to absorb water is between the permanent wilting point and field capacity $(\mathrm{pF}=2.0)$, also called the effective water/moisture/level. However, the interval guaranteeing the normal growth of the plant is from the initial wilting point to the field capacity. The water level in this interval is also called the effective optimum water level. In general, the optimum water level is approximately $50 \%$ to $70 \%$ of the effective water level.

\section{Results and Discussion}

Rainwater harvesting-based irrigation technology is designed in two main parts, i.e. the rainwater reservoir and the irrigation system. The reservoir is a tank built by digging out the soil between the rainwater catchment area and cultivation area. Here, the elevation of the tank location should be higher than that of the cultivation area to enable the gravity-flow of water. Figure 1 shows a built rainwater reservoir.

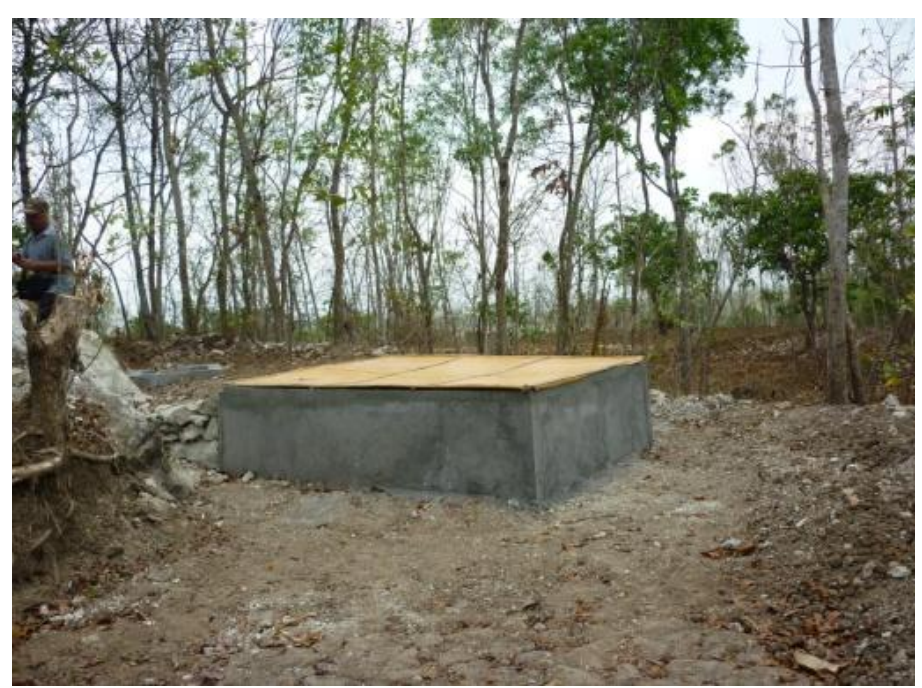

Figure 1 A Rainwater Reservoir Model

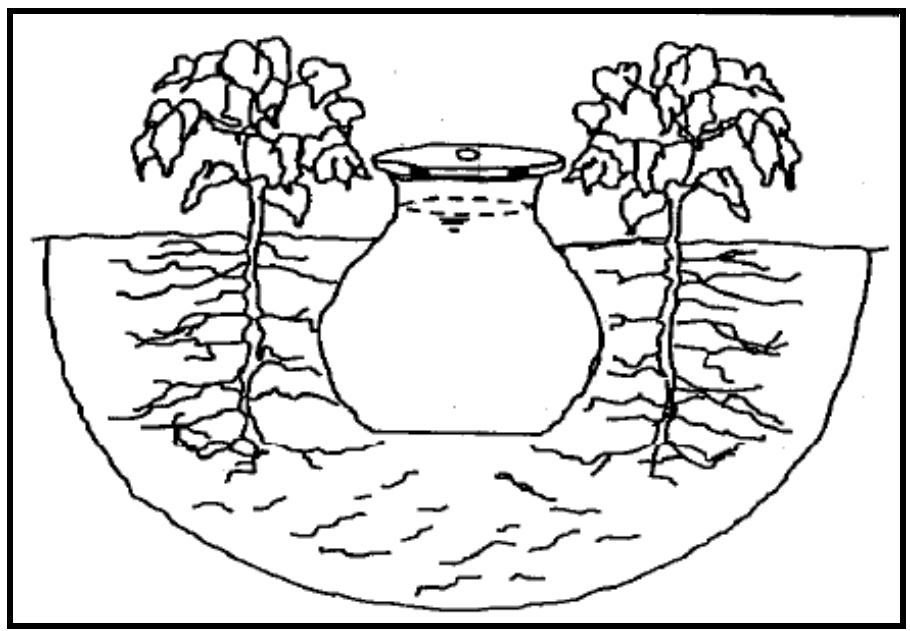

Figure 2 Illustration of Pitcher Irrigation System [5]

Prior to flowing to the reservoir, the rainwater runoff will flow into a sewage tank that has been connected to the reservoir using PVC pipes. From the reservoir, water flows through taps in the PVC pipes. The tap is manually opened and connected to a plastic hose to allow the flow of water to the cultivation area through the irrigation system.

Sub-surface irrigation systems in the form of pitcher irrigation and perforated pipe irrigation are chosen based on the literature review and the characteristics of the research site. The choice of such irrigations is based on the following considerations:

- This irrigation technology can save water by reducing evaporation, percolation, and surface runoff.

- The porous pitcher wall can control water percolation according to the saturation of soil around the pitcher (autoregulative)

- It is suitable for any level of user capability.

- All components can use local products.

- Water supply is flexible: manual, semi automatic, or automatic.

The pitcher irrigation system can use an unglazed clay pitcher sized $30 \mathrm{~cm}$ in diameter and $60 \mathrm{~cm}$ in height. The installation begins by burying the 2.5 litre volume pitcher in the ground down to its neck before planting the crops around the pitcher. 
The advantage of pitcher irrigation as a sub-surface irrigation system is the possibility of direct water supply to plant root zones for the reduction of evaporation, percolation, and surface runoff [6]. In addition, the porous pitcher wall is able to control water percolation according to the saturation of soil around the pitcher (auto-regulative) [7]. Other advantages of pitcher irrigation are that pitcher irrigation is suitable for any level of user capability and most of its components can be made of local products [8][9].

The perforated pipe irrigation system also has potential for providing a limited wetting zone around the pipe. In addition, water is delivered to root zones with percolation rates as needed by the plants. As a result, water loss due to evaporation and percolation can be minimized. The distance between pipes is 40 $\mathrm{cm}$ to $60 \mathrm{~cm}$ because the horizontal moisture level at this range can be distributed evenly.

The analysis of the technical feasibility of irrigation models for both the reservoir and irrigation system is conducted from the hydrological performance perspective. Having an area of 1446.9604 $\mathrm{m}^{2}=0.14469604 \mathrm{ha}$, the catchment area in the research site is characterized by hilly, rocky, and farming area.

Table 1 Maximum Daily Precipitation in Ngawen Station [10]

\begin{tabular}{ll}
\hline Year & Max. R24 $(\mathbf{m m})$ \\
\hline 2002 & 87 \\
2003 & 68 \\
2004 & 47 \\
2005 & 37 \\
2006 & 44 \\
2007 & 65 \\
\hline
\end{tabular}

Based on the data in Table 1 above, where $\mathrm{R}_{24}$ is the rainfall in a 24 hour period, an analysis of peak discharge is then conducted using the frequency analysis of Log Pearson III method with 6 hours for concentration time (tc).

Table 2 Average, Standard Deviation, and Skewness

\begin{tabular}{|c|c|c|c|c|c|}
\hline Year & $\begin{array}{l}\text { Max. R24 } \\
(\mathrm{mm})\end{array}$ & $\log R_{24}$ & $\begin{array}{l}\log 24-^{-} \\
\text {LogR24rt }\end{array}$ & $\begin{array}{l}{\left[\log 24^{-}\right.} \\
\operatorname{LogR24rt}]^{2}\end{array}$ & $\begin{array}{l}{\left[\log 24^{-}\right.} \\
\operatorname{LogR24rt}^{3}\end{array}$ \\
\hline 2002 & 87 & 1.939519 & 0.194737 & 0.037922 & 0.007385 \\
\hline 2003 & 68 & 1.832509 & 0.087727 & 0.007696 & 0.000675 \\
\hline 2004 & 47 & 1.672098 & -0.07268 & 0.005283 & -0.00038 \\
\hline 2005 & 37 & 1.568202 & -0.17658 & 0.031181 & -0.00551 \\
\hline 2006 & 44 & 1.643453 & -0.10133 & 0.010268 & -0.00104 \\
\hline 2007 & 65 & 1.812913 & 0.068131 & 0.004642 & 0.000316 \\
\hline Total & & & & 0.096992 & 0.001446 \\
\hline Average & & 1.744782 & & & \\
\hline $\mathrm{n}$ & 6 & & & & \\
\hline S & 0.139278 & & & & \\
\hline $\mathrm{Cs}$ & 0.160560 & & & & \\
\hline Log R24rt & 1.744782 & & & & \\
\hline
\end{tabular}

From the peak discharge analysis with various return periods, it was found that the minimum discharge occurs at 1.o1-year return period in which $Q=0.000615 \mathrm{~m}^{3} / \mathrm{sec}$, and results in the runoff volume of $\mathrm{V}=13.2818 \mathrm{~m}^{3}$. It is assumed that only $60 \%$ of the runoff has potential to flow into the reservoir. Hence, the potential volume in the reservoir is $\mathrm{V}=7.9691 \mathrm{~m}^{3}$.

The next aspect was the irrigation system model. With 1 x 1 x 1.5 $\mathrm{m}$ - $\operatorname{tank}\left(\mathrm{V}=1.5 \mathrm{~m}^{3}\right)$, the number of tanks required to reserve runoff from a $1446.9604 \mathrm{~m}^{2}$ catchment area is formulated as follows:

\section{Tank needed $=7.9691 / 1.5=5.3$ or 6 tanks}

The first irrigation channel system is the pitcher system. The pitcher volume is 2.5 liters or $2500 \mathrm{~cm}^{3}$. According to the laboratory research, the model pitcher has $\mathrm{k}=0.00001408 \mathrm{~cm} / \mathrm{s}$. Table 3 describes the calculation of the empty-pitcher period due to water percolation through the pitcher wall. The results show that the period required to empty the pitcher is 3.34 days.

According to Table 4, a $1.5-\mathrm{m}^{3}$ tank can support a maximum land parcel of $24.75-\mathrm{m}^{2}, 120$ plants at most, and requires 66 days for service time (the relatively short planting calendar is for green beans) with an assumption that the number of plants along the land's width is 10. The optimum range of pitcher water is around $25 \mathrm{~cm}$ with $50-\mathrm{cm}$ spacing between plants, and one pitcher serves four (4) plants.

The number of pitchers that can be buried determines the maximum land size to be served and can be calculated for several types of tanks with volumes of $3 \mathrm{~m}^{3}$ and $6 \mathrm{~m}^{3}$. The table below presents the maximum land size that can be served based on the tank volume and minimum 6o-day planting calendar (Table 5).

Perforated pipe is the second irrigation channel system. It is mounted near the root zone $(10 \mathrm{~cm}-25 \mathrm{~cm})$ at the depth of 17.5 $\mathrm{cm}$ with $25 \mathrm{~cm}$ left-right spacing between plants. The pipe is in an L-shape; one side is mounted underground while the other side is above the land surface for water supply. One pipe can serve 10 plants. The actual evapotranspiration of the research site is 3.66575 $\mathrm{mm}$ /day with the temperature of $23-27^{\circ} \mathrm{C}$, and $25 \mathrm{~km} /$ hour for the wind speed. To calculate the water demand in the area with subsurface irrigation, the evaporation is first calculated using the following empirical formula:

$$
E=0.35\left(e_{a \mathbb{a}}-e_{\mathbb{Q}}\right)\left(1+\frac{V}{100}\right)
$$

The calculated evaporation of $E$ is $3.56713917 \mathrm{~mm} /$ day, so the water demand $=$ transpiration $=$ difference between actual evaporation and calculated evaporation is $0.098614255 \mathrm{~mm} /$ day. Table 6 represents the calculation results when a pipe is filled once for 10 plants.

Table 3 Calculation of Empty-Pitcher Period

\begin{tabular}{|c|c|c|c|c|c|c|c|}
\hline $\begin{array}{l}\text { Pitcher's k } \\
(\mathrm{cm} / \mathrm{s})\end{array}$ & $\begin{array}{l}\text { height of } \\
\text { cylinder } \\
\text { surface }(\mathbf{c m})\end{array}$ & $\begin{array}{l}\text { cylinder } \\
\text { surface area } \\
\left(\mathrm{cm}^{2}\right)\end{array}$ & $\begin{array}{l}\text { discharge of pitcher } \\
\text { percolation }\left(\mathrm{cm}^{3} / \mathrm{sc}\right)\end{array}$ & $\begin{array}{l}\text { pitcher } \\
\text { volume (L) }\end{array}$ & $\begin{array}{l}\text { pitcher } \\
\text { volume }\left(\mathrm{cm}^{3}\right)\end{array}$ & $\begin{array}{l}\text { empty-pitcher } \\
\text { period } \\
\text { (s) }\end{array}$ & $\begin{array}{l}\text { empty- } \\
\text { pitcher } \\
\text { period (days) }\end{array}$ \\
\hline 0.00001408 & 14 & 615.44 & 0.008662444 & 2.5 & 2,500 & $288.602,16$ & 3,34 \\
\hline
\end{tabular}

Table 4 Service of One Tank

\begin{tabular}{|c|c|c|c|c|c|c|c|c|}
\hline $\begin{array}{l}\text { No. of } \\
\text { pitchers }\end{array}$ & $\begin{array}{l}\text { Empty-tank } \\
\text { period (days) }\end{array}$ & $\begin{array}{l}\text { No. of } \\
\text { plants }\end{array}$ & $\begin{array}{l}\text { No. of plants } \\
\text { along the width }\end{array}$ & $\begin{array}{l}\text { No. of plants } \\
\text { along the length }\end{array}$ & $\begin{array}{l}\text { Land } \\
\text { width }(\mathrm{cm})\end{array}$ & $\begin{array}{l}\text { Land } \\
\text { length }(\mathrm{cm})\end{array}$ & $\begin{array}{l}\text { Land area } \\
\left(\mathrm{cm}^{2}\right)\end{array}$ & $\begin{array}{l}\text { Land area } \\
\left(\mathrm{m}^{2}\right)\end{array}$ \\
\hline 10 & 200.4182 & 40 & 10 & 4 & 450 & 150 & 67500 & 6.75 \\
\hline 15 & 133.6121 & 60 & 10 & 6 & 450 & 250 & 112500 & 11.25 \\
\hline 20 & 100.2091 & 80 & 10 & 8 & 450 & 350 & 157500 & $15 \cdot 75$ \\
\hline 25 & 80.16727 & 100 & 10 & 10 & 450 & 450 & 202500 & 20.25 \\
\hline 30 & 66.80606 & 120 & 10 & 12 & 450 & $55^{\circ}$ & 247500 & 24.75 \\
\hline
\end{tabular}

Table 5 Land Area and Maximum Number of Plants Supported by One Tank

\begin{tabular}{|c|c|c|c|c|c|c|c|}
\hline Tank volume $\left(\mathrm{m}^{3}\right)$ & 1.5 & 3 & 6 & 9 & 12 & 15 & 18 \\
\hline Max. land size $\left(\mathrm{m}^{2}\right)$ & 24.75 & 56.25 & 114.75 & 174.86 & 234.64 & 294.43 & 354.21 \\
\hline Max. number of plants & 120 & 260 & 520 & 787 & 1053 & 1319 & 1584 \\
\hline
\end{tabular}


Table 6 Calculation of Water Demand for One-Time Filling of One Pipe

\begin{tabular}{ll}
\hline Item & Value \\
\hline Soil $\mathrm{k}(\mathrm{cm} / \mathrm{sec})$ & 0.0003296 \\
Pipe length $(\mathrm{cm})$ & 200 \\
$\mathrm{r}(\mathrm{cm})$ & 25 \\
Plant surface area $(20 \times 200)\left(\mathrm{cm}^{2}\right)$ & 4000 \\
Discharge $Q$ up to $\mathrm{r}=25 \mathrm{~cm}\left(\mathrm{~cm}^{3} / \mathrm{sec}\right)$ & 1.3185341 \\
Plant's water demand $(\mathrm{mm} /$ day $)$ & 0.0986143 \\
Required discharge $\left(\mathrm{cm}^{3} /\right.$ day $)-$ for 1 plant & 39.4457019 \\
Demand of 1 pipe / 10 plants $\left(\mathrm{cm}^{3} /\right.$ day) & 394.457019 \\
Demand of 1 pipe /10 plants (liter/day) & 0.39445702 \\
Frequency of pipe filling per day & 1 \\
Period to reach $25 \mathrm{~cm}$ (hour) & 21.067168 \\
\hline
\end{tabular}

Table 7 Service by One $1.5-\mathrm{m}^{3}$ Tank

\begin{tabular}{|c|c|c|c|c|c|c|}
\hline No. of pipes & No. of plants & $\begin{array}{l}\text { Empty-tank period } \\
\text { (day) }\end{array}$ & $\begin{array}{l}\text { Empty-tank period } \\
\text { (month) }\end{array}$ & $\begin{array}{l}\text { No. of pipes along } \\
\text { the width }\end{array}$ & $\begin{array}{l}\text { No. of pipes along } \\
\text { the length }\end{array}$ & $\begin{array}{l}\text { Served land size } \\
\left(\mathrm{m}^{2}\right)\end{array}$ \\
\hline 4 & 40 & 950.67392 & 31.689131 & 2 & 2 & 6.75 \\
\hline 8 & 80 & $475 \cdot 33696$ & 15.844565 & 2 & 4 & 14.25 \\
\hline 12 & 120 & 316.89131 & 10.563044 & 3 & 4 & 23.75 \\
\hline 16 & 160 & 237.66848 & $7 \cdot 9222827$ & 4 & 4 & 33.25 \\
\hline 20 & 200 & 190.13478 & 6.3378261 & 4 & 5 & 42 \\
\hline 24 & 240 & 158.44565 & 5.2815218 & 4 & 6 & 50.75 \\
\hline 28 & 280 & 135.81056 & 4.5270187 & 4 & 7 & 59.5 \\
\hline 32 & 320 & 118.83424 & 3.9611413 & 4 & 8 & 68.25 \\
\hline 36 & 360 & 105.63044 & $3 \cdot 5210145$ & 4 & 9 & 77 \\
\hline 40 & 400 & 95.067392 & 3.1689131 & 4 & 10 & 85.75 \\
\hline 44 & 440 & 86.424902 & 2.8808301 & 4 & 11 & 94.5 \\
\hline 48 & 480 & 79.222827 & 2.6407609 & 4 & 12 & 103.25 \\
\hline 52 & 520 & 73.128763 & 2.4376254 & 4 & 13 & 112 \\
\hline 56 & 560 & 67.90528 & 2.2635093 & 4 & 14 & 120.75 \\
\hline 60 & 600 & 63.378261 & 2.1126087 & 4 & 15 & 129.5 \\
\hline
\end{tabular}

Table 8 Service Period Based on Tank Volume and Number of Pipes

\begin{tabular}{|c|c|c|c|c|c|c|c|c|}
\hline Number of Pipes & & 20 & 60 & 100 & 140 & 180 & 220 & 260 \\
\hline \multirow{3}{*}{ Service Period (day) } & Tank $V=1.5 \mathrm{~m}^{3}$ & 190.1348 & 63.37826 & 38.02696 & 27.16211 & 21.12609 & 17.28498 & 14.6257 \\
\hline & Tank V $=3 \mathrm{~m}^{3}$ & 380.2696 & 126.7565 & 76.05391 & $54 \cdot 32422$ & 42.25217 & 34.56996 & 29.2515 \\
\hline & Tank $\mathrm{V}=6 \mathrm{~m}^{3}$ & 760.5391 & 253.5130 & 152.1078 & 108.6484 & 84.504348 & 69.139921 & 58.50301 \\
\hline
\end{tabular}

Table 9 Maximum Land Size and Maximum Number of Plants to be Served by Different Tank Capacities

\begin{tabular}{|c|c|c|c|c|c|c|c|}
\hline Tank volume $\left(\mathrm{m}^{3}\right)$ & 1.5 & 3 & 6 & 9 & 12 & 15 & 18 \\
\hline Max. land size $\left(\mathrm{m}^{2}\right)$ & $129 \cdot 5$ & 260.75 & 523.25 & 785.75 & 1048.25 & 1310.75 & 1573.25 \\
\hline Max. number of plants & 600 & 1200 & 2400 & 3600 & 4800 & 6000 & 7200 \\
\hline
\end{tabular}

Table 10 Performance Comparison Based on Minimum 6o-Day Planting Calendar

\begin{tabular}{lllllll}
\hline Tank Volume $\left(\mathbf{m}^{3}\right)$ & $\mathbf{1 . 5}$ & $\mathbf{3}$ & $\mathbf{6}$ & $\mathbf{9}$ & $\mathbf{1 2}$ & $\mathbf{1 5}$ \\
\hline Pitcher & & & & & & \\
Max. land size $\left(\mathrm{m}^{2}\right)$ & 24.75 & 56.25 & 114.75 & 174.86 & 234.64 & 294.43 \\
Max. No. of plants & 120 & 260 & 520 & 787 & 1053 & 1319 \\
$\begin{array}{l}\text { Perforated Pipe } \\
\text { Max. land size }\left(\mathrm{m}^{2}\right)\end{array}$ & 129.5 & 260.75 & 523.25 & 785.75 & 1048.25 & 1310.75 \\
Max. No. of plants & 600 & 1200 & 2400 & 3600 & 4800 & 1584 \\
\hline
\end{tabular}

Table 7 illustrates the required period to empty the water in a tank and the land size that can be served by a $1.5-\mathrm{m}^{3}$ tank.

The use of various volumes of tank and the number of pipes will result in different service periods.

Table 8 shows the service periods based on tank volume and number of pipes.

Each tank has a capacity to serve different maximum land sizes and different numbers of plants. This maximum land size is based on the shortest service period, which is 60 days as required for green beans (Table 9).

All the descriptions show a performance comparison between both models with the use of the same tank volume (Table 10).

The perforated pipe medium has more advantages than the pitcher medium. As seen in the table, with a $1.5-\mathrm{m}^{3}$ tank, the pitcher medium can only serve a maximum of $24.75-\mathrm{m}^{2}$ land, while the perforated pipe medium is able to serve up to $129.5-\mathrm{m}^{2}$ land. The factors that make the perforated pipe medium better are:
1. The period to empty the pitcher is long, i.e. around 3 days; hence, it is difficult to control water supply to the pitcher based on water demand of the plants; thus, the supply is merely based on pitcher capacity/volume.

2. The water supply to perforated pipes can be undertaken manually using a dipper and funnel; hence, it is easier to control water supply based on water demand and water is fully used for transpiration. Meanwhile, the use of a hose to supply water will be more costly and make the control of the supply based on water demand for the plants more difficult.

\section{Conclusions}

The conclusions of the analysis are:

1. The rainwater reservoir with perforated pipe and pitcher irrigation system is a model of rainwater harvesting-based 
irrigation technology that can be developed in the research site.

2. The potential of the catchment area in the research site is able to support the existence of a rainwater reservoir at $7.9691 \mathrm{~m}^{3}$

3. The service capacity of one $1.5-\mathrm{m}^{3}$ tank with an assumption of a 6o-day planting calendar is able to drain water into $24.75^{-}$ $\mathrm{m}^{2}$ of land using the pitcher system and into $129 \cdot 5-\mathrm{m}^{2}$ land by using the perforated pipe system.

With regards to its relevance to sustainability, this paper describes methods for harvesting and irrigation using local rainwater. The research addresses the problem of seasonal lack of rainwater, which can be applied to enable agriculture on marginal land in areas where other water sources are scarce or unsustainable.

\section{Acknowledgements}

This research paper would not have been possible without the support of Direktorat Penelitian dan Pengabdian Masyarakat/DitLitabMas (Directorate for Research and Community Service) Directorate General Higher Education, Ministry of Education and Culture who has sponsored this research through National Strategic Scheme (Strategis Nasional). The authors wish to express the appreciation as well to Directorate for Research and Community Service (DPPM) and the Department of Environmental Engineering of Universitas Islam Indonesia (UII). The community of Ngawen and students of UII who have assisted the research are appreciated. Special appreciation is for Erin Joakim PhD from University of Waterloo for her English proof reading.

\section{References}

[1] BPS (Statistics Agency) of Gunungkidul Regency, 2012, Kabupaten Gunungkidul Dalam Angka Tahun 2011 (Gunungkidul Regency in Figures 2011), Gunungkidul: Statistics Agency of Gunungkidul Regency, 2012

[2] Brontowiyono, Widodo, Ribut Lupiyanto, Feris Firdaus, Penyusunan Strategi Penguatan Daya Dukung Lingkungan di Lahan Kritis Daerah Gunungkidul Provinsi DIY (Designing Strategies for Strengthening the Environmental Carrying Capacity of Critical Lands in Gunungkidul Regency of DIY Province), Laporan Hibah Bersaing DIKTI (DIKTI's Competitive Grant Report), Yogyakarta: Islamic University of Indonesia (UII). 2010

[3] Settlement and Regional Infrastructure Agency (Dinas Kimpraswil) of DIY Province, Arah Pengembangan Sumberdaya Air Provinsi DIY (Water Resources Development Direction of DIY Province), Yogyakarta, 2006

[4] Haryati, U., Irigasi Suplemen dan Strategi Implementasinya Pada Pertanian Lahan Kering (Supplementary Irrigation and its Implementing Strategies in Dry Land Agriculture), Agricultural Research and Development Agency, Sinartani, 2011

[5] Hermantoro, Pengembangan Sistem Irigasi Pipa Gerabah Bawah Permukaan Pada Lahan Kering (Development of Sub-Surface Clay-Pipe Irrigation System in Dry land), National Seminar on Agricultural Mechanization 2006.

[6] Edward, Kinerja Sistem Irigasi Kendi Untuk Tanaman Di Daerah Kering (Performance of Pitcher Irrigation System for Dry Land Crops), Dissertation, Postgraduate Program of Bogor Institute of Agriculture, 2000

[7] Molden, D. and Fraiture, C., Comprehensive Assessment of Water Management in Agriculture, International Journal of Agricultural Water Resources Development, 97(4), pp. 493-578. 2009

[8] Calow, R. C., Howarth, S. E. \& Wang, J., Irrigation Development and Water Rights Reform in China, International Journal of Water Resources Development, 25(2), pp. 227-248. 2009

[9] Mori, K., Ishii, H., Somatani, A., Hatakeyama, A., Manual on Hydrology, Association for International Technical Promotion, Translator: Ir.L.Taulu, Dipl.H, Editor: Suyono Sosrodarsono and
Kensaku Takeda, Tenth Edition, 2006, PT. Pradnya Paramita, Jakarta, 2009

[10] PUPESDM Agency (Public Work, Energy, Mineral Resources Agency of DIY Province), Studi Pembangunan Embung untuk Irigasi $d i$ Gunungkidul (Study for Lake Development in Gunungkidul), Yogyakarta, 2009 